\title{
Origin of fluids and related barite deposits at vent sites along the Peru convergent margin
}

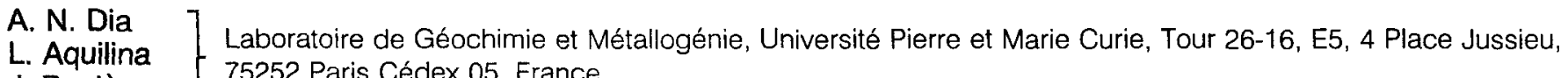 \\ J. Boulègue 75252 Paris Cédex 05, France \\ J. Bourgois Laboratoire de Géodynamique, Tectonique et Environnement, Tour 26-16, E4, 4 Place Jussieu, \\ 75252 Paris Cédex 05, France \\ E. Suess ] Forschungsinstitut für Marine Geowissenschaften, Christian-Albrechts Universität, D-2300 Wischhofstrasse 1-3, \\ M. Torres $]$ Kiel 14, Germany
}

\begin{abstract}
The venting at the northern Peru convergent margin, unlike at other margins, has produced large barite deposits, which have not been observed outside the vents. The ${ }^{87} \mathrm{Sr} /{ }^{86} \mathrm{Sr}$ isotopic ratios of the fluids are more radiogenic than seawater. To explain these elevated values, we propose either the influence of a fluid characterized by a more radiogenic signature originating from the continent, or a reaction between seawater and the underlying continental metamorphic basement. The presence of this nonlocal radiogenic component is marked more strongly on the ${ }^{87} \mathrm{Sr} /{ }^{86} \mathrm{Sr}$ ratios measured in the barite deposits. We assume that the fluid sampled at the venting site and the fluid responsible for the barite deposit sampled at the same site originated from the same source, i.e., the Paleozoic metamorphic basement of the Andean continental margin.
\end{abstract}

\section{INTRODUCTION}

The nature and origin of fluids in convergent margins have been investigated through geochemical and isotopic studies of venting fluids and pore fluids (Boulègue et al., 1987a; Elderfield et al., 1990; Kastner et al., 1990, 1991). However, the extensive work done during the past ten years was dedicated mainly to active margins exhibiting well-developed accretionary prisms, including the Nankai (Claypool et al., 1986; Boulègue et al., 1987a, 1987b), Barbados (Westbrook and Smith, 1983; Westbrook et al., 1988), and Oregon-Cascadia (Carson et al., 1990) margins. Little work was done on the fluid regime of Andean-type convergent margins, where subduction-related erosion processes (Scholl et al., 1980) occur at depth. The first significant work regarding pore fluids of an Andean-type convergent margin is based on samples recovered during Ocean Drilling Program Leg 112 (Suess et al., 1988; Kastner et al., 1990) off Peru.

Subduction-zone fluids can have two types of sources, internal and external. The possible internal sources are (1) pore fluids included in the sediment and/or the fluids contained in the oceanic crust expelled by porosity-reduction processes (Bray and Karig, 1985; Bangs et al., 1990; Davis et al., 1990; Bekins and Dreiss, 1992); (2) fluids formed through diagenetic or metamorphic dehydration, or produced from the breakdown of hydrous minerals (Kastner et al., 1991); and (3) fluids due to biogenic or thermogenic decomposition of organic matter (Kastner et al., 1990; Peacock, 1990; Vrolijk et al., 1990). Sea water and/or mixing with meteoric or even deep water are considered as external sources. Whether the source is internal or external, transport through a complex system of faults can be considered (Kastner et al., 1990; Le Pichon et al., 1990).

One of the main purposes of the Nautiperc cruise (March-April 1991), using the submersible vessel Nautile, was to acquire new insights into the hydrogeologic system along the nonaccreting convergent margin off Peru (Fig. 1). Fluids and associated barite deposits from vents located along the Andean convergent margin between lat $5^{\circ}$ and $7^{\circ} \mathrm{S}$ have been sampled at depths ranging from 2500 to $5400 \mathrm{~m}$ below sea level (Bourgois et al., 1992), with the aim of elucidating the nature of the fluids and thus their possible sources.

\section{GEOLOGIC SETTING}

Water samples were collected during the Nautiperc cruise from four sites: Paita, Chiclayo, Chimbote, and Mendana (Fig. 1). Here we focus only on data from the Paita and Chiclayo areas.

SeaBeam bathymetry (Bourgois et al., 1988) has greatly aided knowledge of these two areas. The main morphological features distinguished in the Paita area include the following (Fig. 2). (1) A 400-700-m-high scarp marks the upper slope-middle slope boundary. This upper-slope scarp is a major detachment fault that dips $45^{\circ}$ seaward and penetrates the continental margin down to 3-5 $\mathrm{km}$ below sea floor (Bourgois et al., 1988). (2) A 1000-1200-m-high middle-slope scarp is located $10 \mathrm{~km}$ seaward from the upper slope scarp. (3) A 300-500-m-high subduction scarp is at the base of the lower slope. This complex scarp system trends north and parallels the trench axis. Interpretation of the CDP-3 multichannel seismic line (Von Huene et al., 1986) reconsidered in the light of Nautiperc cruise data (Fig. 2) allows us to infer the position of the continental

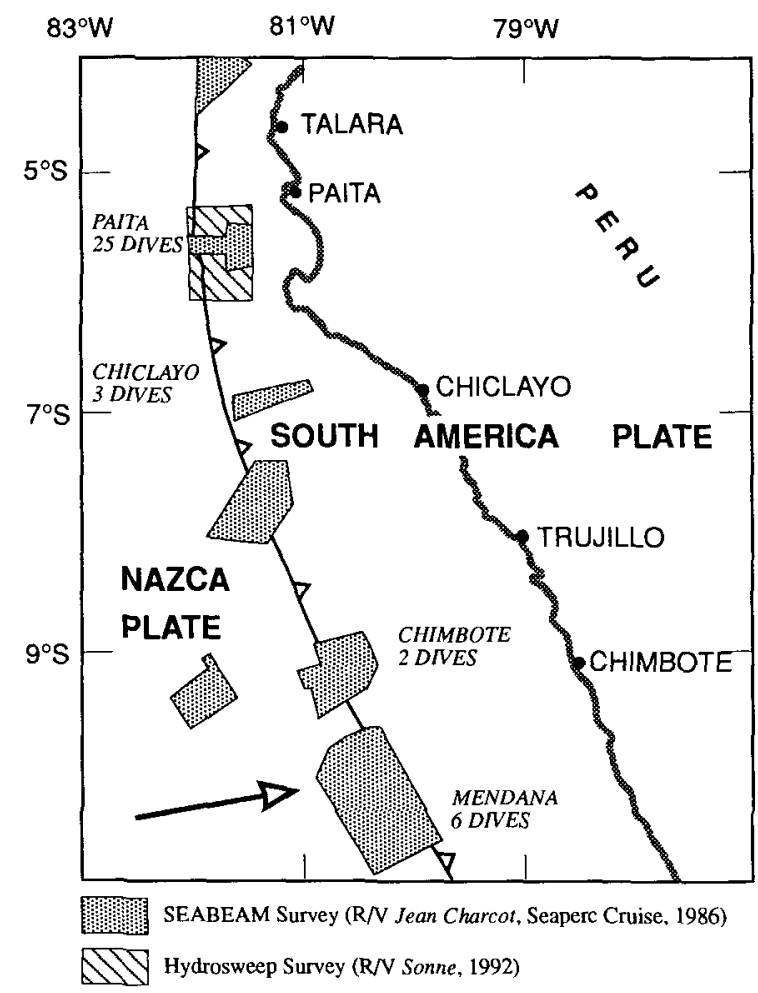

Figure 1. Location of dives made during Nautiperc cruise, March-April 1991. 


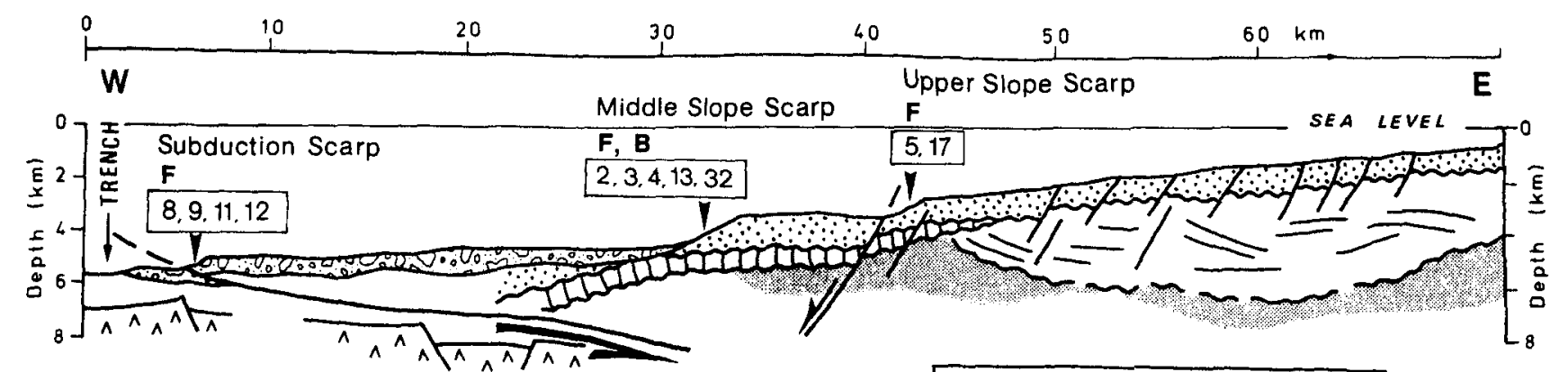

CDP-3 LINE OFF PAITA

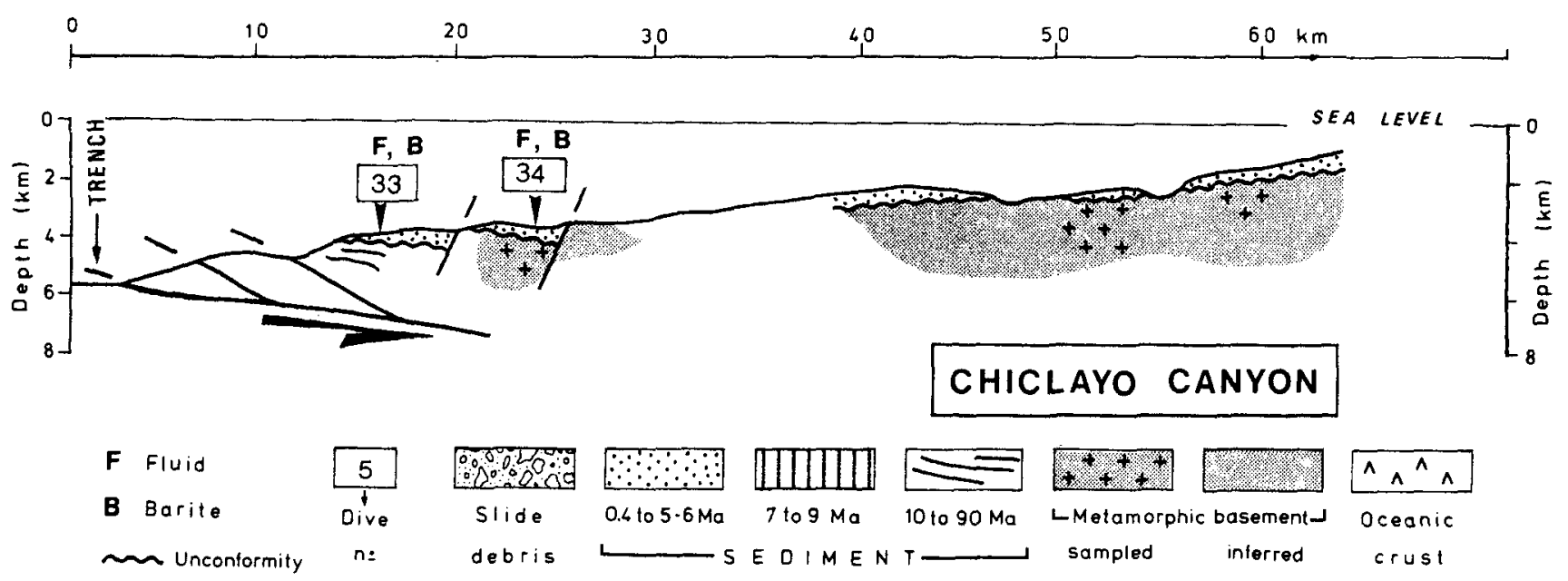

Figure 2. Seaward extension of continental metamorphic basement along CDP-3 multichannel selsmic line off Paita and Chiclayo canyon transect.

metamorphic basement at depth in the area of the middle slope and upper slope scarp areas (Bourgois et al., 1992, 1993).

The Chiclayo canyon (Sosson et al., 1992), $100 \mathrm{~km}$ south of the Paita area, trends east-northeast, perpendicular to the trench axis. The three dives in the canyon explored large continental metamorphic basement outcrops, indicating that the Paleozoic basement known on land extends down to the lower slope area (Fig. 2). The east-trending normal faults, which penetrate deeply the basement rock on land, also extend down to the lower slope.

We assume that the fluid flow across the continental margin off northern Peru is influenced by (1) the east-trending normal-fault network explored in the Chiclayo canyon, and (2) a north-trending fault network, which includes a major detachment fault in the Paita area.

\section{FLUID VENTING AND BARITE DEPOSITS}

In the Paita and Chiclayo canyon areas, the venting of fluid is associated with the presence of dense biological communities composed of live colonies of clams, tube worms (Serpula), and small patches of bacterial mats, as seen elsewhere on convergent margins (Suess et al., 1985; Kulm et al., 1986; Boulègue et al., 1987b; Dron et al., 1987; Moore and Vrolijk, 1992). In the Paita area (Figs. 1 and 2), the fluid samples were collected along the subduction scarp and the middle slope scarp as well as along the upper slope scarp. The largest known vent site on active margins, not only in terms of its total surface $\left(\sim 4000 \mathrm{~m}^{2}\right)$ but also in terms of the density of the distribution of benthic organisms, was discovered along the middle slope scarp; it has thick barite deposits closely related to vents. In the Chiclayo canyon, fluid vents were sampled during two dives (Figs. 1 and 2), one $15 \mathrm{~km}$ and the other $25 \mathrm{~km}$ landward from the trench axis. Both sites are associated with thick barite deposits. No barite deposits were found outside of the fluid-venting sites.
The fluids were collected with titanium syringes above the seawater-sediment interface, as well as in the sediment itself. Local bottom seawater was sampled for reference in the Paita area away from any fluid venting.

\section{ORIGIN OF THE FLUIDS: GEOCHEMICAL AND ISOTOPIC CONSTRAINTS}

Determination of $\mathrm{pH}$ and alkalinity of the fluid samples was done on the ship. Samples for shore-based analysis of major and trace elements and $\mathrm{Sr}$ isotope values were filtered (Nuclepore 0.1 $\mu \mathrm{m})$ and acidified with ultrapure nitric acid. Major and trace element concentrations were determined either by flame atomic absorption, Zeeman corrected flameless atomic absorption, or inductively coupled plasma or ion chromatography.

$\mathrm{Sr}$ isotopic compositions were determined by thermal ionization mass spectrometry. A mean value of $0.710259 \pm 0.000026$ for 25 repeated analyses of the NBS 987 standard has been obtained over the course of the study.

In all the fluid samples, the $\mathrm{pH}$ is comparable to that of common seawater. The chloride content is slightly higher (551 to $567 \mathrm{mM}$ for the Paita area and 558 to $560 \mathrm{mM}$ for the Chiclayo canyon area) than that of IAPSO standard seawater $(546 \mathrm{mM})$, and that of the local reference bottom seawater $(546 \mathrm{mM})$. Clay-membrane filtration and subsequent formation of saline fluids may explain the elevation of the chloride content, as has been suggested for pore fluids recovered along the Peru margin (Suess et al., 1988; Kastner et al., 1991), or it may be a result of clathrate formation producing a residual brine characterized by high density and chlorinity (Kastner et al., 1991). The sulfate content ( 26.90 to $28.40 \mathrm{mM}$ ) measured in the samples from the Paita and Chiclayo areas does not reveal any significant variation from the reference water $(28.23 \mathrm{mM})$. Alkalinity data com- 
pared to total dissolved carbonate values (Table 1) show that all these fluids have concentrations above the expected range for deep Pacific Ocean water (Broecker and Peng, 1982), suggesting an evolution compatible with carbonate dissolution and the decay of organic matter. Therefore, in order to decouple the original signatures of the fluid, we need tracers that are not affected by diagenesis related to seep processes at the sea floor, and whose contents are not modified by passage through the biological communities (Boulègue et al., 1987b).

Alkaline metal ( $\mathrm{Li}, \mathrm{K}$, and $\mathrm{Rb})$, alkaline-earth metal $(\mathrm{Mg}, \mathrm{Ca}$, and $\mathrm{Sr}$ ), and $\mathrm{Co}, \mathrm{Pb}, \mathrm{Cd}, \mathrm{Cu}$, and $\mathrm{Mo}$ contents vary within the range of common bottom seawater. Barium is the only trace element that shows significant variations (Fig. 3). This could be related to advection of nonlocal deep water enriched in $\mathrm{Ba}$. However, changes in $\mathrm{Ba}$ content through biological interaction cannot be completely ruled out.

The $\mathrm{Sr}$ isotope analysis done on the fluids from the Paita and Chiclayo areas show values higher or at least equivalent to that of common bottom seawater, which is $0.709192 \pm 0.000013$ (Dia et al., 1992b). These radiogenic values (Fig. 4) are as high as 0.709323 \pm 0.000019 (Dia et al., 1992a). To explain such elevation of the $\mathrm{Sr}$ isotopic ratios relative to seawater, we need the influence of a fluid characterized by a more radiogenic signature, which can result from reaction between seawater with the underlying continental metamorphic basement or with radiogenic clastic sediments. Thus, the major result from this set of data is that, even when the seawater isotopic composition is strongly recorded in these fluids because of the method of collecting samples (considerable dilution by the ambient seawater), another component characterized by a radiogenic signature must also be present. Therefore, the isotopic signature of this advected end member is not strongly marked, even if it is significant with respect to analytical error. The problem is then to identify this nonlocal component.

The low (compared to seawater) Sr isotopic ratios (whole-rock analyses between $0.708100 \pm 0.000009$ and $0.709091 \pm 0.000014$; Aquilina et al., 1992) measured in sediments collected at venting sites

TABLE 1. DATA FROM PAITA AND CHICLAYO CANYON

\begin{tabular}{|c|c|c|c|c|c|c|c|}
\hline Location & Sample & $\begin{array}{l}\text { Alkalinity } \\
(\mathrm{mM})\end{array}$ & $\begin{array}{l}\Sigma \mathrm{CO}_{2} \\
(\mathrm{mM})\end{array}$ & $\underset{(\mathrm{m})}{\text { Depth }}$ & ${ }^{87} \mathrm{Sr}^{86}{ }^{8 \mathrm{Sr}}$ & $2 \sigma$ & $\underset{(\mathrm{nM})}{\mathrm{Ba}}$ \\
\hline \multirow[t]{2}{*}{ Paita upper slope scarp } & 5 & 2.82 & 2.70 & 2582 & 0.709194 & 0.000016 & 27.67 \\
\hline & 17 & 2.56 & 2.37 & 2632 & 0.709206 & 0.000015 & 24.75 \\
\hline \multirow[t]{5}{*}{ Paita middle slope scarp } & 2 & 2.59 & 2.29 & 3347 & 0.709203 & 0.000010 & 27.67 \\
\hline & 3 & 2.62 & 2.44 & 4000 & 0.709161 & 0.000011 & 26.94 \\
\hline & 4 & 2.56 & 2.38 & 3554 & 0.709323 & 0.000019 & 25.48 \\
\hline & $32 b$ & 2.70 & 2.32 & 3534 & 0.709268 & 0.000009 & 136.16 \\
\hline & $32 r$ & 2.75 & 2.50 & 3549 & 0.709189 & 0.000009 & 86.64 \\
\hline Paita lower slope scarp & 13 & 2.75 & 2.40 & 3006 & 0.709284 & 0.000010 & 52.42 \\
\hline \multirow[t]{5}{*}{ Paita subduction scarp } & $8-1$ & 2.65 & 2.40 & 5187 & 0.709280 & 0.000016 & 26.21 \\
\hline & $8-2$ & 3.25 & 2.92 & 4950 & 0.709272 & 0.000018 & - \\
\hline & 9 & 2.52 & 2.20 & 5040 & 0.709211 & 0.000012 & 22.57 \\
\hline & 11 & 2.62 & 2.22 & 5131 & 0.709274 & 0.000018 & 32.77 \\
\hline & 12 & 2.80 & 2.61 & 4842 & 0.709255 & 0.000012 & 29.85 \\
\hline \multirow[t]{3}{*}{ Chiclayo canyon } & 33 & 2.82 & 2.50 & 3711 & 0.709191 & 0.000010 & 122.32 \\
\hline & 34 & 2.62 & 2.32 & 4174 & 0.709268 & 0.000013 & 73.54 \\
\hline & Std IAPSO & . & - & - & 0.709192 & 0.000013 & - \\
\hline
\end{tabular}

Note : Dash indicates no data.

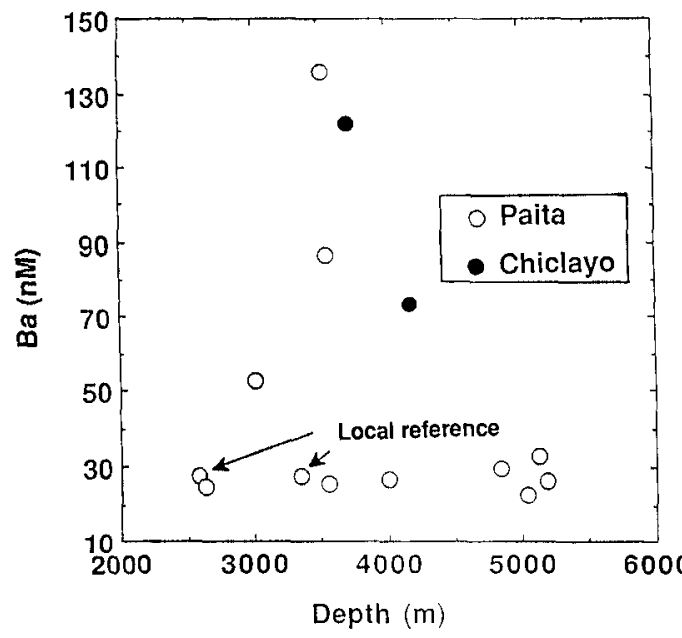

Figure 3. Ba content vs. depth at studied sites.

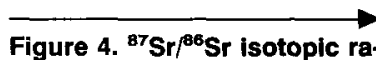
tios vs. depth, $95 \%$ confidence limit.

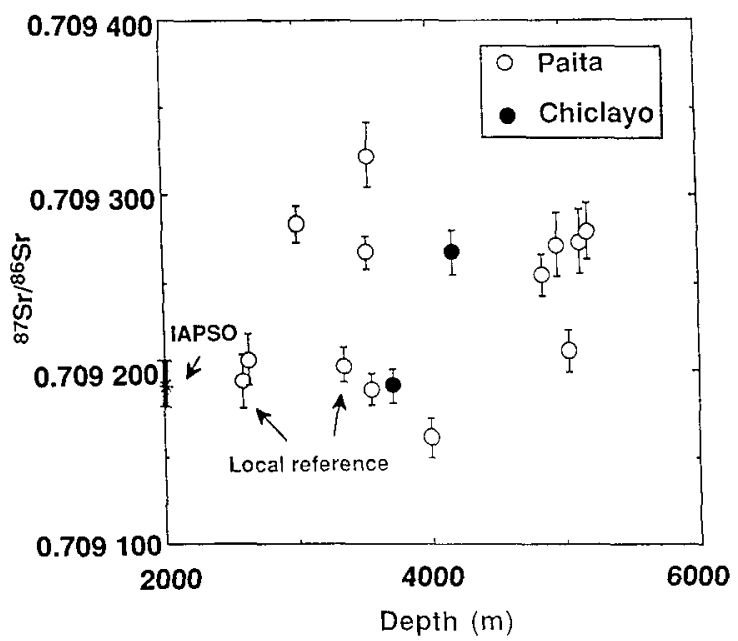


in the Paita area rule out the hypothesis of interaction between sediments and seawater to generate radiogenic fluids, and thus to explain the origin of these fluids. However, the high $\mathrm{Sr}$ isotopic ratios measured $(0.710152 \pm 0.000010$ to $0.711118 \pm 0.000012)$ in the massive barite deposits (Aquilina et al., 1992) reveal a radiogenic component of the fluid responsible for the deposition of the barite. We think that the fluid sampled at venting sites and the fluid responsible for the barite deposit sampled at the same site came from the same source. Therefore, we assume that the fluids collected during the Nautiperc cruise derived, at least in part, from the interaction with the Paleozoic continental metamorphic basement that forms the Andean basement onshore. The fluids could come directly either from continental aquifers through a complex plumbing system or from underplating of continental material removed continentward by subduction erosion.

\section{SUMMARY AND CONCLUSIONS}

Major and trace element analysis coupled with Sr isotope measurements on samples of venting fluids and closely associated barite deposits allows for characterization of the origin of the fluids. (1) Most trace element contents do not show any major change relative to seawater composition. (2) A Ba enrichment of venting fluids was observed at all sites. (3) The Sr isotope ratios of the venting fluid and barite deposits indicate that the venting fluids and the fluid responsible for the barite deposition derived mostly from the metamorphic basement of the Andean continental crust, and thus may have the same origin. Assuming that the $\mathrm{Sr}$ isotopic ratio anomalies of venting fluid and barite deposits at the same site originated from the same source, we infer that the Ba enrichment of fluid collected during the Nautiperc cruise is related to advection of nonlocal deep water. The fluids originated from the Andean basement.

\section{ACKNOWLEDGMENTS}

The Nautiperc cruise was supported by Institut Français de Recherche pour l'Exploitation de la Mer, Institut National des Sciences de l'Univers, Centre National de la Recherche Scientifique, the Bundesministerium für Forschung und Technologie (Bonn) and the Forschunginstitut für Marine Geowissenschaften GEOMAR. Part of the analytical work was done by A.-M. De Kersabiec, F. Vidot, D. Dubarry, and Y. Meinnel. We thank C. J. Allègre for allowing Dia access to mass spectrometry facilities, and J. Sample, P. Froelich, and anonymous reviewers for thorough and constructive reviews.

\section{REFERENCES CITED}

Aquilina, L., Dia, A.N., Boulègue, J., Fouillac, A.-M., Suess, E., Von Breymann, M., and Bourgois, J., 1992, Geochemistry of barite and carbonate deposits associated with fluid vents in the Peru convergent margin off Paita [abs.]: Eos (Transactions, American Geophysical Union), v. 73, p. 153.

Bangs, N., Westbrook, G.K., Ladd, J.W., and Buhl, P., 1990, Seismic velocities from the Barbados Ridge Complex: Indicators of high pore fluid pressure in an accretionary complex: Journal of Geophysical Research, v, 95, p. $8767-8782$.

Bekins, B., and Dreiss, S., 1992, Parameters controlling dewatering in accretionary prisms: Earth and Planetary Science Letters, v. 109, p. 275-287.

Boulègue, J., Iiyama, J.T., Charlou, J.-L., and Jedwab, J., 1987a, Nankai Trough, Japan Trench and Kuril Trench: Geochemistry of fluids sampled by submersible "Nautile": Earth and Planetary Science Letters, v. 83, p. 363-375.

Boulègue, J., Bénédetti, E.L., Dron, D., Mariotti, A., and Létolle, R., 1987b, Geochemical and biogeochemical observations on the biological communities associated with fluid venting in the Nankai Trough and Japan Trench subduction zones: Earth and Planetary Science Letters, v. 83, p. 343-355.

Bourgois, J., and 11 others, 1988, SeaBeam and seismic reflection imaging of the tectonic regime of the Andean continental margin off Peru (4 to $\left.7^{\circ} \mathrm{S}\right)$ : Earth and Planetary Science Letters, v. 87, p. 116-126.

Bourgois, J., Michaud, F., Von Breymann, M., Suess, E., and Nautiperc Cruise Shipboard Scientists, 1992, Northern Peru convergent margin: Massive slides from the upper plate into the trench axis observed from a submersible [abs.]: Eos (Transactions, American Geophysical Union), v. 73, p. 152.

Bourgois, J., Lagabrielle, Y., De Wever, P., Suess, E., and Nautiperc Cruise Shipboard Scientists, 1993, Tectonic history of the northern Peru convergent margin during the past $400 \mathrm{ka}$ : Geology, v. 21, p. 531-534.

Bray, C.J., and Karig, E.D., 1985, Porosity of sediments in accretionary prisms and some implications for dewatering processes: Journal of Geophysical Research, v. 90 , p. $768-778$.

Broecker, W.S., and Peng, T.H., 1982, Tracers in the sea: New York, Eldigio Press, $690 \mathrm{p}$.

Carson, B., Suess, E., and Strasser, J.C., 1990, Fluid flow and mass flux determinations at vent sites on the Cascadia margin accretionary prism: Journal of Geophysical Research, v. 95, p. 8891-8897.

Claypool, G.E., Vuletich, A.K., and Kvenvolden, K.A., 1986, Isotopic composition of interstitial fluids in sediment of the Nankai Trough, in Kagami, H., Karig, D.E., et al., Initial reports of the Deep Sea Drilling Project, Volume 87: Washington, D.C., U.S. Government Printing Office, p. 857-860.

Davis, E., Hyndman, R.D., and Villinger, H., 1990, Rates of fluid expulsion across the Cascadia accretionary prism: Constraints from new heat flow and multichannel seismic reflection data: Journal of Geophysical Research, v. 95, p. $8869-8889$

Dia, A.N., Aquilina, L., Boulègue, J., Suess, E., Von Breymann, M., and Bourgois, J., 1992a, Fluids from the Peru subduction vents: Trace element and isotopic constraints [abs.]: Eos (Transactions, American Geophysical Union), v. 73, p. 153.

Dia, A.N., Cohen, A.S., O'Nions, R.K., and Shackleton, N.J., 1992b, Seawater Sr isotope variation over the past $300 \mathrm{kyr}$ and influence of global climate cycles: Nature, v. 356, p. 386-388.

Dron, D., Boulègue, J., Taira, A., and Rangin, C., 1987, Geochemistry of the Teryu Canyon deep-sea fan biological community (Kaiko): Earth and Planetary Science Letters, v. 83, p. 356-362.

Elderfield, H., Kastner, M., and Martin, J.B., 1990, Compositions of sources of fluids in sediments of the Peru subduction zone: Journal of Geophysical Research, v. 95, p. 8819-8827.

Kastner, M., Elderfield, H., Martin, J.B., Suess, E., Kvenvolden, K.A., and Garrison, R.E., 1990, Diagenesis and interstitial water chemistry at the Peruvian continental margin: Major constituents and strontium isotopes, in von Huene, R., Suess, E., et al., Initial reports of the Ocean Drilling Program, Volume 112: College Station, Texas, Ocean Drilling Program, p. 413-440.

Kastner, M., Elderfield, H., and Martin, J.B., 1991, Fluids in convergent margins: What do we know about their composition, origin, role in diagenesis and importance for chemical fluxes?: Royal Society of London Philosophical Transactions, ser. A, v. 335 , p. $243-259$.

Kulm, L.D., and 13 others, 1986, Oregon subduction zone: Venting, fauna and carbonates: Science, v. 231 , p. $561-566$.

Le Pichon, X., Henry, P., and Lallemant, S., 1990, Water flow in the Barbados accretionary complex: Journal of Geophysical Research, v. 95, p. $8945-8967$.

Moore, J.C., and Vrolijk, P., 1992, Fluids in accretionary prisms: Reviews of Geophysics, v. 30, p. 113-135.

Peacock, S.M., 1990, Fluid processes in subduction zones: Science, v. 248 p. $321-337$.

Scholl, D.W., Von Huene, R., Vallier, T.L., and Howell, D.G., 1980, Sedimentary masses and concepts about tectonic processes at underthrust ocean margins: Geology, v. 8, p. 564-568.

Sosson, M., Mercier de Lépinay, B., Bourgois, J., De Wever, P., Michaud, F., Barron, J., and Fourtanier, E., 1992, Deep sea dives in the Chiclayo canyon, northern Peru: Tectonic regime in the Andean convergent margin [abs.] EOS (Transactions, American Geophysical Union), v. 73, p. 152.

Suess, E., Carson, B., Ritger, S., Moore, J.C., Jones, M., Kulm, L.D., and Cochrane, G., 1985, Biological communities at vent sites along the subduction zones off Oregon, in Jones, M.C., ed., The hydrothermal vents of eastern Pacific: An overview: Biological Society of Washington Bulletin, v. 6, p. $475-484$.

Suess, E., Von Huene, R., and Leg 112 Shipboard Scientists, 1988, Ocean Drilling Program Leg 112, Peru continental margin: Part 2, Sedimentary history and diagenesis in a coastal upwelling environment: Geology, v. 16, p. 939-943.

Von Huene, R., Kulm, L., Miller, J., and Hussong, D., 1986, The Peru continental margin, record sections 2 and 3, in Von Huene, R., ed., Seismic images of modern convergent margin tectonic structures: American Association of Petroleum Geologists Studies in Geology, v. 26, p. 32-33.

Vrolijk, P., Chambers, S., Gieskes, J., and O'Neil, J., 1990, Stable isotope ratios of interstitial fluids from the northern Barbados accretionary prism, ODP Leg 110 , in Moore, M., et al., Proceedings of the Ocean Drilling Program, Volume 110: College Station, Texas, Ocean Drilling Program, p. 181-205.

Westbrook, G.K., and Smith, M.J., 1983, Long decollement and mud volcanoes: Evidence from the Barbados Ridge Complex for the role of high pore-fluid pressure in the development of an accretionary complex: Geology, v. 11, p. $279-283$.

Westbrook, G.K., Ladd, J.W., Buhl, P., Bangs, N., and Tiley, G., 1988, Cross section of an accretionary wedge: Barbados Ridge complex: Geology, v. 16, p. $631-635$.

Manuscript received June 2, 1993

Revised manuscript received August 31, 1993

Manuscript accepted September 16, 1993 